\title{
Morphometrics and gill function in Gammarus duebeni (Peracarida: Amphipoda) inhabiting a sewage treatment works
}

\author{
S. D. Roast*, M. B. Jones \\ School of Biological Sciences, University of Plymouth, Drake Circus, Plymouth PL4 8AA, UK
}

\begin{abstract}
Gills from a population of Gammarus duebeni (Liljeborg), isolated after colonising the humus tanks of a sewage treatment works, were measured by image analysis and compared with those from a population in an adjacent estuary. Gill length, width, perimeter, area and lamellar area were all significantly larger for amphipods inhabiting the sewage treatment works compared with their estuarine counterparts (believed to be the parent population). However, the relative contribution of lamellae to overall gill area was smaller in individuals from the sewage works, indicating that the peripheral sinus that surrounds the gill is wider in this population. Humus tanks constitute an extreme environment compared with the adjacent estuary, having constant hypoxia and elevated concentrations of dissolved trace metals, particularly zinc. Accumulation of zinc was examined in sewage works G. duebeni following different periods of acclimation to 'clean' water, to test whether differences in gill morphometrics were accompanied by differences in gill physiology/function. Amphipods acclimated to 'clean' water for 6 and $10 \mathrm{wk}$ accumulated less zinc than those without acclimation. Exposure salinity also affected zinc accumulation, but no clear trends were discernible. Increased gill size in sewage works amphipods indicates that oxygen uptake is more critical than minimising metal uptake for G. duebeni inhabiting the humus tanks. However, there are no obvious explanations for the effects of acclimation or salinity on metal uptake.
\end{abstract}

KEY WORDS: Gills · Trace metals $\cdot$ Sewage $\cdot$ Gammarus $\cdot$ Population

Resale or republication not permitted without written consent of the publisher

\section{INTRODUCTION}

For many years, populations of organisms that have become isolated from the main distributional range of that particular species have been used to study the development of morphological, physiological and behavioural differences within species (Lockwood 1993). In 1973, a sewage treatment works (STW) was opened at the Cornish resort of Looe. Of conventional design, it was unusual in function as, due to a tidallybased influx of seawater, it operated with saline rather than the more typical freshwater sewage (Jones \& Johnson 1992). Two species of amphipod, Orchestia gammarellus (Pallas) and Gammarus duebeni (Liljeborg), colonised the STW from the adjacent estuary, although recruitment stopped soon after the STW was opened (Jones \& Wigham 1988). The STW, therefore, contains isolated populations of $O$. gammarellus and G. duebeni, providing a 'natural experiment' to test the long-term responses of organisms to extreme conditions, as the STW has elevated concentrations of trace metals (especially zinc) and permanent hypoxia (Johnson \& Jones 1989, Jones \& Johnson 1992). To date, work on O. gammarellus at the STW has been limited to population structure (Jones \& Wigham 1993). In contrast, several studies have been reported for the population of $G$. duebeni in the STW, including their tolerance to trace metal exposure, tolerance to hypoxia, and the skewed sex ratio within the population compared with the estuarine 'parent' population (see Agnew \& Jones 1986, Johnson \& Jones 1989, Jones \& Johnson 1992). 
The aim of the present study was to investigate whether isolation in the humus tanks has led to morphological or structural changes of Gammarus duebeni. In particular, we investigated whether the gill dimensions of STW amphipods were different from the native, estuarine population. Several studies have addressed interspecific differences in the gill morphometrics of amphipods (e.g. Moore \& Taylor 1984, Spicer \& Taylor 1986, Marsden 1991, Steele \& Steele 1991), but there are few data on intraspecific differences. A second aim of the present study was to investigate whether there were any differences in accumulation of zinc following acclimation of STW amphipods to clean water. Since the gills are a primary route of trace metal uptake (Rainbow 1995, 1997), differences in trace metal accumulation might indicate alteration of gill function. Finally, since the STW is subject to marked alterations in salinity, the effect of salinity on zinc accumulation was also investigated in STW amphipods.

\section{MATERIALS AND METHODS}

During summer 1994, Gammarus duebeni were collected from the humus tanks of the STW and from the adjacent East Looe River Estuary, Cornwall, UK $\left(50^{\circ} 21^{\prime} \mathrm{N}, 4^{\circ} 27^{\prime} \mathrm{W}\right)$ (see Jones \& Johnson 1992). STW amphipods were sampled by sweeping an FBA (Freshwater Biology Association) dip-net (1 mm mesh size) through the surface waters of the humus tanks; estuarine amphipods were sampled by sweeping an FBA dip-net in the shallow water at the estuary edge. Amphipods were transported to the laboratory in water collected from their respective habitats. Six gills from the left side of 30 similar-sized male amphipods (body length $13 \pm$ $1 \mathrm{~mm}$ ) from each habitat were dissected from the limb base (see Barnes 1987, p. 646) and stored individually in $5 \%$ buffered seawater formalin. Gill length, width, perimeter, total area and lamellar area were measured using a Sony 3CCD camera linked to a Quantimet 570 Image Analyser (Cambridge Instruments).

Additional STW amphipods were collected for laboratory studies. Amphipods were maintained in the laboratory in 121 plastic aquaria $\left(20 \pm 1 \% ; 15 \pm 0.5^{\circ} \mathrm{C}\right)$ and fed Tetra Marin ${ }^{\circledR}$ flake food ad libitum. Following acclimation to 'clean' water (20\% made by combining double-distilled water with filtered seawater; no added zinc) for 0, 6 and $10 \mathrm{wk}$, male STW amphipods of similar size $(13 \pm 1 \mathrm{~mm})$ were exposed to $10,20,30,40$ and $50 \mathrm{mg} \mathrm{l}^{-1}$ zinc (as $\mathrm{ZnSO}_{4}$; Sigma Chemical Company) for $96 \mathrm{~h}$. In addition, male STW amphipods (13 $\pm 1 \mathrm{~mm})$ were exposed to $10,20,30,40$ and $50 \mathrm{mg} \mathrm{l}^{-1}$ zinc at salinities of $1,10,20$ and $30 \%$ (made by combining double-distilled water with filtered seawater) for $96 \mathrm{~h}$. Corresponding controls (no added zinc) were made simultaneously. All exposures were made in $500 \mathrm{ml}$ plastic beakers; there were 5 amphipods in each beaker and 10 replicates for each treatment. Water samples were taken to compare nominal with measured concentrations. Following metal exposure, individual amphipods were sacrificed by freezing, freezedried for $24 \mathrm{~h}$ (Edwards Freeze Dryer), weighed

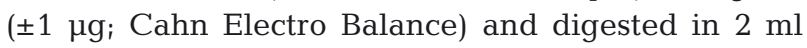
$\mathrm{H}_{2} \mathrm{NO}_{3}$ (ANALAR, BDH). Digestion was approximately $90 \%$ complete and the supernatant was analysed for zinc content using atomic absorption spectrophotometry (Varian AA-975 calibrated with deuterium background correction).

Statistical treatment of results. Gills from 30 STW amphipods were compared with gills from 30 estuarine amphipods. Gill length, width, perimeter, area and lamellar area were compared using repeated measures analysis of variance (ANOVA), with individual blocked in the analysis to account for 6 gills being used from each individual amphipod. Body burden data were analysed using a 2-factor ANOVA to examine the effects of exposure concentration $\times$ acclimation period, and exposure concentration $\times$ exposure salinity. Follow-up analyses were made using Tukey's Honestly Significant Difference (HSD) test to identify any differences found by the ANOVA. All statistical analyses were performed using Statgraphics Plus Version 5.1 (Statistical Graphics).

Table 1. Gammarus duebeni. Gill area morphometrics for 2 populations. STW = sewage treatment works population; $\mathrm{EST}=$ estuarine population. Data are means $\pm 95 \%$ confidence intervals. Bold type-face indicates significant difference between STW and EST population for that gill number (Tukey's HSD, $\mathrm{p}<0.05$ ). $\mathrm{n}=30$ for each gill number from each population

\begin{tabular}{|c|c|c|c|}
\hline Dimension & $\begin{array}{c}\text { Gill } \\
\text { number }\end{array}$ & STW & EST \\
\hline \multirow[t]{6}{*}{ Length } & 1 & $1.683( \pm 0.053)$ & $1.430( \pm 0.054)$ \\
\hline & 2 & $1.803( \pm 0.056)$ & $1.569( \pm 0.046)$ \\
\hline & 3 & $1.841( \pm 0.043)$ & $1.646( \pm 0.065)$ \\
\hline & 4 & $1.826( \pm 0.037)$ & $1.637( \pm 0.079)$ \\
\hline & 5 & $1.533( \pm 0.040)$ & $1.388( \pm 0.062)$ \\
\hline & 6 & $1.126( \pm 0.046)$ & $1.089( \pm 0.063)$ \\
\hline \multirow[t]{6}{*}{ Width } & 1 & $1.241( \pm 0.036)$ & $0.973( \pm 0.027)$ \\
\hline & 2 & $1.153( \pm 0.032)$ & $0.938( \pm 0.038)$ \\
\hline & 3 & $1.146( \pm 0.032)$ & $0.926( \pm 0.041)$ \\
\hline & 4 & $1.074( \pm 0.029)$ & $0.919( \pm 0.034)$ \\
\hline & 5 & $1.032( \pm 0.043)$ & $0.925( \pm 0.043)$ \\
\hline & 6 & $0.574( \pm 0.025)$ & $0.585( \pm 0.041)$ \\
\hline \multirow[t]{6}{*}{ Perimeter } & 1 & $6.599( \pm 0.585)$ & $4.852( \pm 0.271)$ \\
\hline & 2 & $5.921( \pm 0.436)$ & $5.344( \pm 0.319)$ \\
\hline & 3 & $5.895( \pm 0.367)$ & $5.497( \pm 0.449)$ \\
\hline & 4 & $6.364( \pm 0.595)$ & $5.655( \pm 0.493)$ \\
\hline & 5 & $6.105( \pm 0.559)$ & $4.655( \pm 0.414)$ \\
\hline & 6 & $4.109( \pm 0.604)$ & $3.866( \pm 0.387)$ \\
\hline
\end{tabular}


Table 2. Gammarus duebeni. Analysis of variance (ANOVA) table for comparing gill dimensions of STW and estuarine amphipods. Amphipods from each population: $\mathrm{n}=30$

\begin{tabular}{|c|c|c|c|}
\hline $\begin{array}{l}\text { Dimension } \\
\text { Source of variation }\end{array}$ & df & $F$ & $\mathrm{p}$ \\
\hline \multicolumn{4}{|l|}{ Length } \\
\hline Gill number & 5 & 242 & $<0.0001$ \\
\hline Population & 1 & 161 & $<0.0001$ \\
\hline Gill number $\times$ Population & 5 & 18.3 & $<0.0001$ \\
\hline Error & 359 & & \\
\hline \multicolumn{4}{|l|}{ Width } \\
\hline Gill number & 5 & 242 & $<0.0001$ \\
\hline Population & 1 & 161 & $<0.0001$ \\
\hline Gill number $\times$ Population & 5 & 18.3 & $<0.0001$ \\
\hline Error & 359 & & \\
\hline \multicolumn{4}{|l|}{ Perimeter } \\
\hline Gill number & 5 & 18.1 & $<0.0001$ \\
\hline Population & 1 & 41.3 & $<0.0001$ \\
\hline Gill number $\times$ Population & 5 & 2.58 & 0.0265 \\
\hline Error & 359 & & \\
\hline \multicolumn{4}{|l|}{ Area } \\
\hline Gill number & 5 & 190 & $<0.0001$ \\
\hline Population & 1 & 140 & $<0.0001$ \\
\hline Gill number $\times$ Population & 5 & 17.5 & $<0.0001$ \\
\hline Error & 359 & & \\
\hline \multicolumn{4}{|l|}{ Lamellar area } \\
\hline Gill number & 5 & 146 & $<0.0001$ \\
\hline Population & 1 & 28.5 & $<0.0001$ \\
\hline Gill number $\times$ Population & 5 & 15.6 & $<0.0001$ \\
\hline Error & 359 & & \\
\hline
\end{tabular}

\section{RESULTS}

\section{Gill morphometrics}

Gill dimensions of STW amphipods differed significantly from those of estuarine amphipods. In general, gill length, width and perimeter of STW amphipods were all larger than in estuarine amphipods (Tables 1 \& 2). Not surprisingly, changes in the length and breadth of each gill led to changes in the gill area (ANOVA, $F=140$, df =5,359, p < 0.001; Table 2). For Gills 1 to 5, STW amphipods had larger areas than estuarine amphipods (Tukey's HSD, p < 0.05; Table 3); there was no difference between the populations for area of Gill 6 (Tukey's HSD, p > 0.05; Table 3). There was, however, a significant interaction between gill number and amphipod population, where differences in area became smaller from anterior to posterior gills (ANOVA, $F=17.5, \mathrm{df}=5,359, \mathrm{p}<0.001$; Tables $2 \& 3$ ). STW amphipods also had a larger lamellar area for Gills 1, 2, 3 and 4 than did estuarine amphipods (ANOVA, $F=28.5, \mathrm{df}=5,359, \mathrm{p}<0.001$; Tables $2 \& 4$ ). However, when lamellar area is expressed as a proportion of total gill area, this relationship is reversed and estuarine amphipods have a larger area of lamellae per unit of total gill area (Table 4).
Table 3. Gammarus duebeni. Gill area relationships for 3 populations. STW = sewage treatment works population $;$ EST = estuarine population; ${ }^{*}$ MILLPORT $=$ values estimated from the regression equation of Moore \& Taylor (1984) for a population of G. duebeni in Millport (Isle of Cumbrae, Scotland). Data are means $\pm 95 \%$ confidence intervals. Bold typeface indicates significant difference between STW and EST population for that gill number (Tukey's HSD, $\mathrm{p}<0.05$ ). $\mathrm{n}=30$ for each gill number from each population

\begin{tabular}{|llcll|}
\hline \multirow{2}{*}{ Gill number } & \multicolumn{1}{c}{ STW } & \multicolumn{2}{c|}{ EST } & ${ }^{*}$ MILLPORT \\
\hline 1 & $\mathbf{1 . 4 0 4}( \pm 0.090)$ & $0.943( \pm 0.057)$ & 1.148 \\
2 & $\mathbf{1 . 4 6 9}( \pm 0.095)$ & $1.035( \pm 0.070)$ & 1.179 \\
3 & $\mathbf{1 . 4 7 6}( \pm 0.099)$ & $1.061( \pm 0.072)$ & 1.241 \\
4 & $\mathbf{1 . 3 7 9}( \pm 0.100)$ & $1.045( \pm 0.078)$ & 1.210 \\
5 & $\mathbf{1 . 1 0 0}( \pm 0.109)$ & $0.947( \pm 0.083)$ & 0.993 \\
6 & $0.448( \pm 0.111)$ & $0.431( \pm 0.083)$ & 0.434 \\
Total & 7.276 & 5.462 & 6.204 \\
\hline
\end{tabular}

\section{Body burden data}

Zinc accumulation by non-acclimated amphipods increased with increasing exposure concentration (ANOVA, $F=4.83$, df $=5,249, \mathrm{p}<0.05$; Fig. 1,

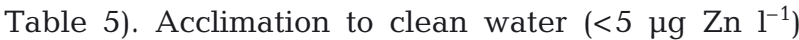
also affected zinc accumulation by Gammarus duebeni significantly (ANOVA, $F=5.91$, df $=2,249, \mathrm{p}<$ 0.02; Fig. 1, Table 5). Acclimated amphipods accumulated less zinc during subsequent exposure than non-acclimated amphipods (Tukey's HSD, p $<0.05$; Fig. 1); however, length of acclimation period had no significant effect on zinc accumulation (Tukey's HSD, p > 0.05; Fig. 1).

Although salinity affected zinc accumulation by nonacclimated STW amphipods significantly (ANOVA, $F=$ 5.44, df =3,249, p < 0.01; Fig. 2, Table 6), no obvious trends were identified.

Table 4. Gammarus duebeni. Comparison of lamellar areas of gills from 2 populations. STW = sewage treatment works population; $\mathrm{EST}=$ estuarine population. Data are means $\pm 95 \%$ confidence intervals. Bold type-face indicates significant difference between STW and EST population for that gill number (Tukey's HSD, $\mathrm{p}<0.05$ ). $\mathrm{n}=30$ for each gill number from each population

\begin{tabular}{|c|c|c|c|c|}
\hline \multirow{2}{*}{$\begin{array}{l}\text { Gill } \\
\text { number }\end{array}$} & \multicolumn{2}{|c|}{ Total lamellar area $\left(\mathrm{mm}^{2}\right)$} & \multicolumn{2}{|c|}{ Proportion } \\
\hline & STW & EST & STW & EST \\
\hline 1 & $\mathbf{0 . 6 2 9 *}^{*}( \pm 0.048)$ & $0.491( \pm 0.040)$ & 0.448 & 0.520 \\
\hline 2 & $\mathbf{0 . 6 3 5}^{*}( \pm 0.048)$ & $0.479( \pm 0.044)$ & 0.432 & 0.463 \\
\hline 3 & $\mathbf{0 . 5 5 1} *( \pm 0.049)$ & $0.425( \pm 0.044)$ & 0.373 & 0.400 \\
\hline 4 & $0.529 \quad( \pm 0.050)$ & $0.455( \pm 0.046)$ & 0.384 & 0.435 \\
\hline 5 & $0.364 \quad( \pm 0.052)$ & $0.430( \pm 0.049)$ & 0.331 & 0.454 \\
\hline 6 & $0.145 \quad( \pm 0.052)$ & $0.158( \pm 0.049)$ & 0.323 & 0.366 \\
\hline Total & 2.854 & 2.438 & 2.291 & 2.638 \\
\hline
\end{tabular}




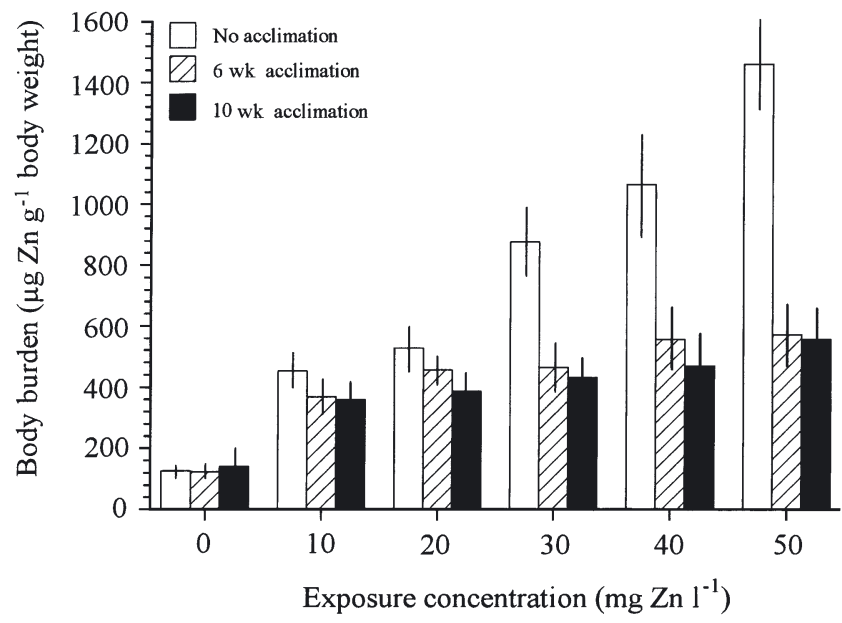

Fig. 1. Gammarus duebeni. Total body zinc burdens of STW amphipods exposed to various concentrations of zinc following acclimation to 'clean' ( $\left.<5 \mu \mathrm{g} \mathrm{Zn} \mathrm{l}^{-1}\right)$ seawater for various time periods. Data are means $\pm 95 \%$ confidence intervals; $\mathrm{n}=50$ per treatment

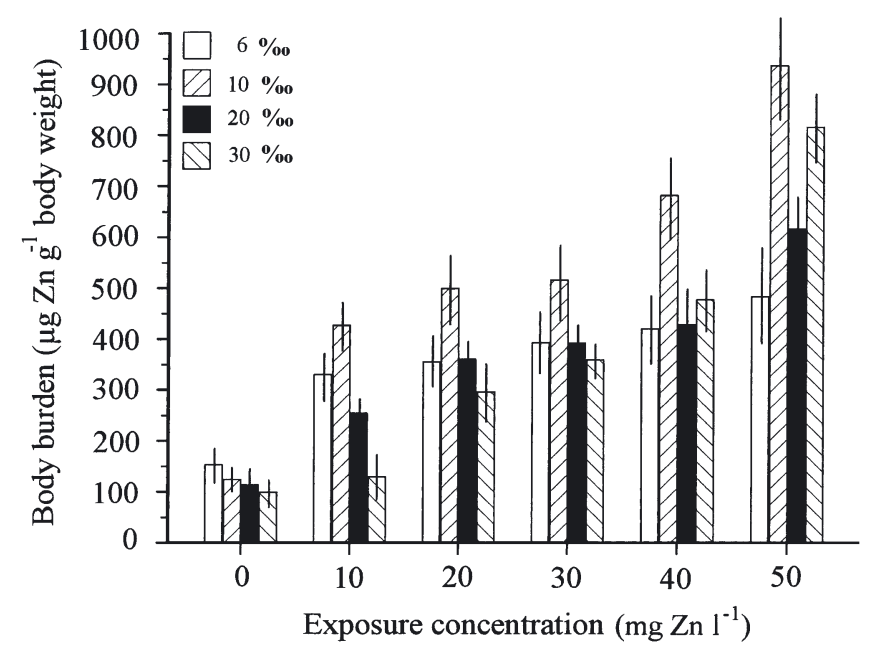

Fig. 2. Gammarus duebeni. Total body burdens of zinc for STW amphipods exposed to various concentrations of zinc at different salinities. Data are means $\pm 95 \%$ confidence intervals; $\mathrm{n}=50$ per treatment

Table 5. Gammarus duebeni. Two-way ANOVA of the effects of acclimation period and exposure concentration on the body burdens of zinc of STW amphipods exposed to zinc at constant salinity (20)

\begin{tabular}{|lrcc|}
\hline Variable & df & $F$ & $\mathrm{p}$ \\
\hline Acclimation & 2 & 5.91 & 0.020 \\
Concentration & 5 & 4.83 & 0.017 \\
Acclimation $\times$ Concentration & 10 & 2.15 & 0.021 \\
Error & 249 & & \\
\hline
\end{tabular}

\section{DISCUSSION}

The present study found that Gammarus duebeni inhabiting the STW had larger gills than the 'parent' population in the adjacent estuary. An immediate conclusion is that a larger gill area is advantageous in the hypoxic environment of the humus tanks (Jones \& Johnson 1992), since the increased surface area to volume ratio would enhance oxygen uptake (amphipod gills are essentially 2-dimensional, having very little depth; Schmitz 1991, Steele \& Steele 1991). Jones \& Johnson (1992) showed that STW G. duebeni have elevated tolerance to hypoxia (i.e. have lower critical oxygen tensions, $p_{c}$ ) compared with estuarine $G$. duebeni, so it is possible that the increased tolerance of STW amphipods is due, at least in part, to them having a larger gill area. However, in addition to dissolved oxygen, the permeable surface of the gills is also a primary route of uptake of trace metals from solution (e.g. Rainbow 1995, 1997). The increased gill area of the STW amphipods might, therefore, be disadvantageous due to the increased potential for entry of the elevated heavy metal concentrations present in the humus tanks. Our results indicate that uptake of oxygen is a more fundamental requirement for survival, leading to larger gill area.

Moving from Gill 1 to Gill 6 (i.e. most anterior gill to most posterior gill), the size difference between the gills of the 2 different populations decreases. It has been suggested that differences in gill area along the body of amphipods is due to selection for the largest gill area to be in the place of highest oxygen availability (Moore \& Taylor 1984). Although gill area relationships are not understood conclusively, it is suggested that reduction in gill area from totally aquatic amphipods, through intertidal to terrestrial amphipods, is a response for reducing desiccation (Moore \& Taylor 1984). However, STW Gammarus duebeni frequently climb up the walls of the humus tanks and rest approximately $20 \mathrm{~mm}$ above the water level, thus becoming totally emersed (S. D. Roast pers. obs.); in comparison, their estuarine counterparts are fully aquatic. Desiccation, therefore, can be discounted as a determinant of gill size in this instance.

Table 6. Gammarus duebeni. Two-way ANOVA of the effects of salinity and exposure concentration on the body burdens of zinc of STW amphipods

\begin{tabular}{|lrcc|}
\hline Variable & df & $F$ & $\mathrm{p}$ \\
\hline Salinity & 3 & 5.44 & 0.001 \\
Concentration & 5 & 19.7 & $<0.0001$ \\
Salinity $\times$ Concentration & 15 & 1.94 & 0.020 \\
Error & 249 & & \\
\hline
\end{tabular}


In addition to the reduced hypoxia (Agnew \& Jones 1986) and elevated concentrations of dissolved metals (e.g. Johnson \& Jones 1989, Jones \& Johnson 1992) in the humus tanks, the other main abiotic difference between the STW and estuarine environments is salinity. Salinity in the humus tanks ranged from ca. 8 to 22 depending on state of the tide in the adjacent estuary (S. D. Roast pers. obs.); the estuarine population experienced salinities from ca. 12 to 33 . Histological studies have revealed that the internal organisation of the gills of Gammarus duebeni is altered when the amphipods are exposed to changes in salinity (e.g. Lockwood et al. 1973, Shires et al. 1994). However, such changes occur in cross-section through the gill, e.g. disruption of the arrangement of lamellae (Shires et al. 1994), and have no effect on the external gill dimensions. Furthermore, it is unlikely that differences in gill morphology are related to ionic regulation, since in amphipods the coxal gills are believed to be respiratory in function only; osmoregulation is believed to be carried out in the sternal gills (where present; Steele \& Steele 1991).

Although STW amphipods also had a larger area of lamellae for most gills, when expressed as a proportion of total gill area, estuarine amphipods have a larger area of lamellae per unit of total gill area. Essentially, this measurement shows that the peripheral sinus that surrounds the lamellar area (Shires et al. 1994) is wider, relative to the area of lamellae, in the STW amphipods than it is in the estuarine amphipods. It is unclear why STW have a wider peripheral sinus, although it infers that larger volumes of haemolymph can be transported to and from the gills at any one time. Again, this might be advantageous for inhabiting a hypoxic environment.

Gammarus duebeni has a variable phenotype regarding its physiology (Lockwood 1992), but the present study suggests that there might also be structural differences between different populations. Indeed, it may be that the physiological plasticity described for G. duebeni (at least in terms of respiratory biology) is, in fact, due to variations in gill structure or size. One other study has reported the gill area relationships of G. duebeni (Moore \& Taylor 1984) and the gill areas recorded were intermediate between those recorded in the present study for STW and estuarine G. duebeni (Table 3). Although there were significant differences between the 2 populations reported in the present study, it is apparent that significant inter-population differences in gill size of natural amphipod assemblages are not unusual.

It is appropriate to highlight here that due to the nature of this type of 'natural experiment' there is no real replicate of the STW environment, so one must be careful in the interpretation of the results. It is clear that interpopulation differences exist in the gill area of Gammarus duebeni, therefore, differences in gill dimensions of STW amphipods might not necessarily be due to treatment effects (i.e. by inhabiting the STW). For example, an alternative hypothesis is that the initial colonisation of the STW was by a biased sample of estuarine amphipods with large gills. If that were the case, the STW population would have larger gills purely by chance, on account of this initial colonisation. Unfortunately there is no way to test such an alternative hypothesis; therefore, conclusions on the cause of the larger gill size of STW amphipods should be made cautiously.

In the present experiments for non-acclimated amphipods, zinc accumulation increased with increasing exposure concentration, presumably due to increased amount of zinc available for uptake. Interestingly, Gam-

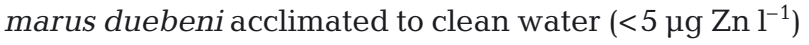
accumulated less zinc during subsequent exposure than non-acclimated amphipods, although length of acclimation period had no significant effect on zinc accumulation. Gammaridean amphipods, and crustaceans in general, are able to eliminate trace metals from their bodies when placed in 'clean' (i.e. metal-free) water. For example, total body concentrations in G. fasciatus decreased by between 35 and $88 \%$ following depuration (Amyot et al. 1996). In the present study, there was no significant difference between any of the control body burdens, which eliminates the possibility that acclimation led to depuration of existing body burdens. It is, therefore, unclear why acclimation to 'clean' water led to reduced metal uptake in the present study; although the acclimation period may have promoted some physiological response which led to decreased accumulation.

Perhaps the most obvious physiological change would be an alteration of apparent permeability by Gammarus duebeni. When placed in a dilute medium, G. duebeni reduces the 'apparent' permeability of its body surface to water flux (e.g. Lockwood et al. 1973, Bolt 1983, Dawson et al. 1984, Lockwood 1993). Furthermore, if acclimated to constant low salinity for a long period, apparent water permeability can decrease still further (Dawson et al. 1984). Regarding uptake of trace metals, it has been suggested that euryhaline crustaceans accumulate less metal in low salinity due to a lowering of the apparent permeability to water of their body surface (e.g. Rainbow \& Black 2001). In the present study, amphipods were acclimated to a salinity of $20 \%$ for up to $10 \mathrm{wk}$, compared with amphipods collected straight from the humus tanks where salinity fluctuated with the tide in the adjacent estuary between 8 and $22 \%$ (S. D. Roast pers. obs.). It is, therefore, unlikely that the amphipods acclimated to $20 \%$ had a lower apparent water permeability than those collected straight from the STW; thus it remains unknown why the acclimated amphipods in the present study accumulated less metal than the non-acclimated ones. 
Interestingly, increasing zinc exposure concentration had no significant effect on zinc accumulation by amphipods acclimated to clean water for 6 or $10 \mathrm{wk}$. Uptake kinetics of trace metals are well documented for some marine crustaceans, e.g. the shore crab Carcinus maenas (Martin \& Rainbow 1998) and the Chinese mitten crab Eriocheir sinensis (Roast et al. 2002). In these crabs, zinc is accumulated (at least in the haemolymph) over time in proportion to the amount of zinc available (Martin \& Rainbow 1998, Roast et al. 2002). A similar pattern was recorded in the present study for non-acclimated amphipods, but not for amphipods acclimated to clean water.

The effect of salinity on zinc accumulation by unacclimated Gammarus duebeni was significant, but unclear. Exposure salinity can affect metal accumulation by crustaceans in several ways. As stated, it is suggested that euryhaline crustaceans lower their apparent water permeability in low salinity, thereby lowering metal uptake (e.g. Rainbow \& Black 2001). Alternatively, metal accumulation may be reduced at salinities approaching the isosmotic point of euryhaline crustaceans, presumably due to reduced osmoregulatory water-flux (e.g. Roast et al. 2002). No clear salinity-dependent trends were recorded in the present study, preventing further interpretation of these results.

The present study has identified differences in gill size between the STW population and the neighbouring estuarine population (believed to be the parent population). Gill parameters vary between natural amphipod populations, but it may be that the increased gill area of STW amphipods is a response to the continuous hypoxia found in the humus tanks. Also, an interesting, and as yet unexplained, zinc accumulation pattern was recorded following acclimation to zinc-free water. Due to engineering works commissioned by South West Water (UK), the STW at Looe now operates on sewage of much lower salinity. However, the population of Gammarus duebeni still exists, further demonstrating the physiological plasticity of this amphipod species.

Acknowledgements. The authors would like to thank South West Water and the staff at the Looe STW for allowing access to the site and providing information regarding operating conditions, and P. Russell (University of Plymouth) for assistance with the image analysis. We would also like to thank J. I. Spicer (University of Plymouth) for constructive criticism throughout the production of this manuscript, and the helpful comments of 4 anonymous referees. S.D.R. was funded by a grant from the Worshipful Company of Fishmongers, for which we are grateful.

\section{LITERATURE CITED}

Agnew DJ, Jones MB (1986) Metabolic adaptations of Gammarus duebeni Liljeborg (Crustacea, Amphipoda) to hypoxia in a sewage treatment plant. Comp Biochem Physiol 84A:475-478

Amyot M, PinelAlloul B, Campbell PGC, Desy JC (1996) Total

Editorial responsibility: Otto Kinne (Editor),

Oldendorf/Luhe, Germany metal burdens in the freshwater amphipod Gammarus fasciatus: contribution of various body parts and influence of gut contents. Freshw Biol 35:363-373

Barnes RD (1987) Invertebrate Zoology, 5th edn. Saunders College Publishing, New York

Bolt SRL (1983) Haemolymph concentrations and apparent permeability in varying salinity conditions of Gammarus duebeni, Chaetogammarus marinus and Gammarus locusta. J Exp Biol 107:129-140

Dawson ME, Morris RJ, Lockwood APM (1984) Some combined effects of temperature and salinity on water permeability and gill lipid composition in the amphipod Gammarus duebeni. Comp Biochem Physiol 78A:729-735

Johnson I, Jones MB (1989) Effects of zinc/salinity combinations on zinc regulation in Gammarus duebeni from the estuary and sewage treatment works at Looe, Cornwall. J Mar Biol Assoc UK 69:249-260

Jones MB, Johnson I (1992) Responses of the brackish-water amphipod Gammarus duebeni (Crustacea) to saline sewage. Neth J Sea Res 30:141-147

Jones MB, Wigham GD (1988) Colonisation by estuarine amphipods of a sewage treatment works. Bull Est Brackish Wat Sci Assoc 50:29-33

Jones MB, Wigham GD (1993) Reproductive biology of Orchestia gammarellus (Crustacea: Amphipoda) living in a sewage treatment works. J Mar Biol Assoc UK 73:405-416

Lockwood APM (1993) Gammarus duebeni: a flexible phenotype. In: Aldrich JC (ed) Proceedings of the 27th European Marine Biology Symposium. JAPAGA, Ashford, p 215-227

Lockwood APM, Inman CBE, Courtney TH (1973) The influence of environmental salinity on the water fluxes of the amphipod crustacean Gammarus duebeni. J Exp Biol 58:137-148

Marsden I (1991) A comparison of water loss and gill areas in two supralittoral amphipods from New Zealand. Hydrobiol 223:149-158

Martin DJ, Rainbow PS (1998) The kinetics of zinc and cadmium in the haemolymph of the shore crab Carcinus maenas (L.). Aquat Toxicol 40:203-231

Moore PG, Taylor AC (1984) Gill area relationships in an ecological series of Gammaridean amphipods (Crustacea). J Exp Mar Biol Ecol 74:179-186

Rainbow PS (1995) Physiology, physicochemistry and metal uptake - a crustacean perspective. Mar Pollut Bull 31:55-59

Rainbow PS (1997) Ecophysiology of trace metal uptake in crustaceans. Estuar Coast Shelf Sci 44:169-175

Rainbow PS, Black WH (2001) Effects of changes in salinity on the apparent water permeability of three crab species: Carcinus maenas, Eriocheir sinensis and Necora puber. J Exp Mar Biol Ecol 264:1-13

Roast SD, Rainbow PS, Smith BD, Nimmo M, Jones MB (2002) Trace metal uptake in the Chinese mitten crab Eriocheir sinensis: the role of osmoregulation. Mar Environ Res 53: 453-464

Schmitz EH (1991) Amphipoda. In: Harrison FW, Humes AG (eds) Microscopic anatomy of invertebrates, Vol 9. John Wiley \& Sons, New York, p 652

Shires R, Lane NJ, Inman CBE, Lockwood APM (1994) Structural changes in the gill cells of Gammarus duebeni (Crustacea, Amphipoda) under osmotic stress; with notes on microtubules in association with the septate junctions. Tissue Cell 26:767-778

Spicer JI, Taylor AC (1986) A comparative study of the gill area relationships in some talitrid amphipods. J Nat Hist 20:935-947

Steele DH, Steele VJ (1991) The structure and organization of the gills of the gammaridean Amphipoda. J Nat Hist 25: $1247-1258$

Submitted: December 17, 2002; Accepted: July 4, 2003

Proofs received from author(s): September 8, 2003 